\title{
Analisis Wacana Perilaku Konsumtif Dalam Film Crazy Rich Asian
}

\author{
Stefanny Harlie, Widayatmoko \\ stefliee09@gmail.com \\ Fakultas Ilmu Komunikasi Universitas Tarumangara
}

\begin{abstract}
This research determine to the consumptive behaviour constructed by Crazy Rich Asian films. The theories in this study are the theory of communication, film, consumptive behavior, consumptive lifestyle and discourse analysis. This study uses descriptive qualitative research methods with discourse analysis used in conjunction with the case study approach. The subjects in this study is Crazy Rich Asian films and the objects in this study is consumptive behaviour. The technique of data collection are from observation and study of literature. Data analysis techniques were carried out using the Teun A.Van Dijk model discourse analysis. The results of this study indicate that the constructed consumptive lifestyle is the way a person displays his identity through the use of time, money and luxury goods that lead to pleasure without thinking of the actual needs. Consumptive lifestyles illustrate the pattern of human life that is controlled and driven by a desire to fulfill the desire for pleasure. Image is the priority because it involves the degree of self and want to always be looked upon by others.
\end{abstract}

Keywords: Discourse Analysis, Consumptive Behaviour and Film

\begin{abstract}
Abstrak
Penelitian ini dilakukan dengan tujuan untuk mengetahui perilaku konsumtif yang dikonstruksikan film Crazy Rich Asian. Teori yang digunakan dalam penelitian ini adalah teori komunikasi, film, perilaku konsumtif, gaya hidup konsumtif dan analisis wacana. Penelitian ini menggunakan metode penelitian kualitatif deskriptif dengan analisis wacana yang digunakan bersama dengan pendekatan studi kasus. Subyek dalam penelitian ini adalah film Crazy Rich Asian dan obyek dalam penelitian ini adalah perilaku konsumtif. Teknik pengumpulan data dilakukan dengan cara observasi dan studi literatur (pustaka). Teknik analisis data yang dilakukan adalah dengan menggunakan analisis wacana model Teun A.Van Dijk. Hasil penelitian ini menunjukkan bahwa perilaku konsumtif yang dikonstruksikan adalah cara seseorang menampilkan identitas dirinya lewat penggunaan waktu, uang dan barang-barang mewah yang mengarah kepada kesenangan tanpa memikirkan kebutuhan yang sebenarnya. Perilaku konsumtif menggambarkan adanya pola hidup manusia yang dikendalikan dan didorong oleh suatu keinginan untuk memenuhi hasrat kesenangan semata. Citra adalah yang diutamakan karena menyangkut derajat diri serta ingin selalu dipandang tinggi oleh orang lain.
\end{abstract}

Kata kunci: Analisis Wacana, Perilaku Konsumtif dan Film

\section{Pendahuluan}

Perkembangan industri yang semakin pesat membuat penyediaan barang masyarakat menjadi berlimpah, masyarakat akan tertarik untuk mengkonsumsi suatu barang karena banyak sekali pilihan yang ada. Persaingan bisnis yang terjadi antar perusahaan juga semakin kompetitif sehingga para produsen saling bersaing untuk meningkatkan level strategi pemasarannya melalui aspek kualitas produk dan juga 
harga demi memberikan kepuasaan kepada konsumen. Perilaku konsumtif merupakan suatu perilaku dimana seseorang memiliki keinginan untuk terus-menerus membeli barang yang kurang diperlukan dan menggunakan suatu produk secara tidak tuntas. Perilaku tersebut membuat seseorang sibuk mementingkan kepentingan pribadi dan tidak memikirkan kepentingan orang lain, hal ini dapat menimbulkan tindakan kriminal seperti pencurian, korupsi, dan lain-lain.

Gaya hidup dapat diartikan sebagai suatu cara hidup seseorang yang diidentifikasi melalui penggunaan waktu, apa yang dianggap penting dalam lingkungan (ketertarikan) serta apa yang dipikirkan tentang diri sendiri dan orang sekitar. Gaya hidup juga dapat diartikan sebagai sebuah karakteristik seseorang yang secara kasat mata menandai sistem nilai dan juga sikap terhadap dirinya sendiri serta lingkungan sekitar.

Seseorang yang memiliki perilaku konsumtif akan membeli apa saja yang diinginkan tanpa memperdulikan jumlah uang yang akan dikeluarkan, Perilaku konsumtif ini dapat terus berkembang di dalam gaya hidup seseorang, tetapi gaya hidup konsumtif juga harus didasari dengan finansial yang memadai. Finansial yang tidak memadai dapat menimbulkan dampak ekonomi, psikologis, sosial dan juga etika. Dampak secara psikologis, seseorang akan mengalami kecemasan yang disebabkan oleh adanya tuntutan untuk membeli barang yang diinginkan tetapi terhalang oleh finansial yang kurang memadai. Sedangkan secara sosial, seseorang akan terus menerus mengikuti perkembangan trend yang ada tanpa memperdulikan jumlah uang yang harus dikeluarkan. Penelitian yang dilakukan penulis memiliki tujuan untuk mengetahui perilaku konsumtif yang dikonstruksikan film Crazy Rich Asian.

\section{Metode Penelitian}

Penelitian ini dilakukan dengan menggunakan metode penelitian kualitatif yang bersifat deskriptif dengan pendekatan analisis wacana yang digunakan bersama dengan pendekatan studi kasus. Penulis memilih metode analisis wacana untuk mempelajari makna pesan yang terdapat dalam sebuah teks ataupun dialog film serta digunakan untuk mempelajari makna pesan yang terdapat pada sebuah wacana ataupun teks film yang diteliti. Menurut Nazir (2011), studi kasus merupakan penelitian mengenai status subjek penelitian yang berkenan dengan suatu fase spesifik ataupun khas dari keseluruhan personalitas. Studi kasus memiliki tujuan untuk memberikan gambaran secara luas mengenai latar belakang, sifat-sifat dan karakter khas dari suatu kasus yang diambil, kemudian akan dijadikan ke dalam suatu hal yang bersifat umum.

Untuk melengkapi penelitian ini diperlukan teknik pengolahan data dan juga analisis data. Teknik pengolahan dan analisis data yang digunakan penulis adalah analisis wacana model Teun A. Van Dijk. Di dalam teks film ataupun dialog yang akan diteliti adalah bagaimana suatu struktur wacana ataupun teks digunakan untuk menegaskan suatu tema tertentu. Van Dijk melihat suatu teks berdasarkan beberapa struktur yang masing-masing bagian saling mendukung. Struktur yang pertama adalah struktur makro yang merupakan makna keseluruhan dari suatu teks yang dapat diamati dengan cara melihat tema atau topik yang dijadikan dasar dalam suatu peristiwa. Struktur yang kedua adalah superstruktur yang merupakan struktur wacana yang berhubungan dengan kerangka suatu teks dan bagaimana bagian-bagian teks tersusun dalam menjelaskan suatu peristiwa secara utuh. Terakhir adalah struktur 
mikro yang merupakan suatu makna wacana yang dapat diteliti dari bagian kecil suatu teks yaitu kalimat, kata dan gambar.

\section{Hasil Temuan dan Diskusi}

Film ini menceritakan tentang bagaimana perilaku konsumtif yang dilakukan secara langsung oleh orang-orang yang memiliki status sosial dari kalangan atas di Singapura. Konsep perilaku konsumtif yang dikontruksikan adalah bagaimana cara seseorang menunjukkan identitas mengenai dirinya sendiri lewat penggunaan uang, waktu serta barang-barang mewah yang lebih mengarah kepada kesenangan semata tanpa memikirkan terlebih dahulu apa yang menjadi kebutuhan utama.

Perilaku konsumtif merupakan perilaku yang disertai dengan adanya kehidupan yang mewah dan juga berlebihan, perilaku konsumtif juga ditunjukan dengan penggunaan segala sesuatu atau hal yang dianggap paling mahal yang mampu memberikan kepuasan baginya dan juga kenyaman fisik. Perilaku konsumtif menggambarkan adanya suatu pola hidup dari seseorang yang secara tidak langsung dikendalikan dan didorong oleh suatu keinginan yang diharapkan dapat memenuhi hasrat keinginan untuk kesenangan semata. Sebuah gaya hidup dapat digunakan untuk mengenal perbedaan kelompok-kelompok dalam masyarakat. Seseorang cenderung menginginkan sesuatu yang dapat menunjukkan gaya hidup untuk menunjukkan siapa dirinya.

Gaya hidup terbentuk di dalam suatu ruang sosial yang di dalamnya juga berisikan aktivitas-aktivitas belanja untuk memenuhi hasrat kesenangan. Masyarakat secara sosial dikontruksikan ke dalam berbagai ruang gaya hidup yang menjadikan seseorang akan bergantung pada citra, status dan juga pergantian gaya. Untuk mengetahui suatu gaya hidup seseorang, dapat dilihat dari barang-barang yang digunakan dan dimiliki. Seseorang yang berasal dari keluarga kaya raya cenderung memiliki gaya hidup konsumtif yang tinggi, orang tersebut akan membeli apa saja yang diinginkan tanpa memikirkan besarnya jumlah uang yang dikeluarkan.

Konsumsi pada masa sekarang tidak lagi didasarkan dengan suatu kebutuhan, tetapi berdasarkan suatu produk yang memiliki symbol atau makna tertentu yang dipercaya dapat menaikkan derajat dirinya. Citra atau image merupakan hal yang paling diutamakan karena menyangkut derajat diri serta ingin selalu dipandang tinggi oleh orang lain. Pada dasarnya seseorang membangun citra diri untuk mendapatkan perhatian dan juga penghargaan diri dari orang lain. Oleh sebab itu orang-orang yang memiliki gaya hidup konsumtif yang tinggi berani untuk mengeluarkan uang dengan jumlah yang banyak untuk membeli barang-barang mewah demi tampil berbeda dari orang-orang lainnya.

Seseorang yang memiliki perilaku konsumtif seperti ini memiliki dampak negatif baik bagi diri sendiri maupun orang lain. Orang tersebut cenderung tidak mau bergaul dan merendahkan orang-orang yang berasal dari kalangan bawah, hal tersebut tentunya sangat merugikan dan membuat orang-orang dari kalangan bawah merasa dikecilkan. Seberapa tinggi pendidikan yang ditempuh tidak akan menjadi faktor utama, orang tersebut menganggap orang-orang yang berada di kalangan bawah tidak layak untuk menjadi bagian dari hidup ataupun keluarganya, yang diinginkan hanyalah orang-orang yang berada di level yang sama sehingga dapat dijadikan partner untuk berbelanja dan menghabiskan uang bersama. Akan tetapi tidak semua orang yang berasal dari keluarga kaya raya memiliki sifat demikian, ada pula orang yang tetap rendah hati dan mau bergaul dengan semua kalangan. 
Uang memang menjadi kebutuhan setiap orang untuk menjalani hidup seharihari, akan tetapi uang bukanlah segalanya. Seseorang tidak dapat hanya mengandalkan uang atau seluruh harta kekayaannya untuk segala hal, uang memang bisa menjanjikan kebahagiaan tetapi itu hanya bersifat sementara, memiliki uang yang banyak belum tentu dapat membahagiakan diri dan keluarga, memiliki uang bukan juga berarti semua masalah bisa diselesaikan begitu saja, uang hanya dapat membeli kesenangan tetapi bukan kebahagiaan dan dalam kondisi tertentu dapat terjadi perpecahan dalam keluarga.

\section{Simpulan}

Konsep perilaku konsumtif yang dikontruksikan adalah bagaimana cara seseorang menunjukkan identitas atau siapa dirinya melalui penggunaan uang, waktu dan juga barang-barang mewah yang lebih mengarah kepada kesenangan tanpa mengutamakan apa yang menjadi dasar dari kebutuhan yang sebenarnya. Konsumsi pada masa sekarang tidak lagi didasarkan dengan kebutuhan, tetapi berdasarkan suatu barang ataupun produk yang memiliki simbol ataupun makna tertentu yang mampu menaikkan derajat dirinya.

Citra atau image merupakan hal yang paling diutamakan karena menyangkut derajat diri serta ingin selalu dipandang tinggi oleh orang lain. Seseorang yang berperilaku konsumtif tinggi cenderung tidak mau bergaul dengan orang-orang yang berstatus sosial dari kalangan bawah. Pendidikan tidak menjadi faktor penentu untuk bergaul, yang diutamakan adalah orang-orang yang memiliki level yang sederajat sehingga dapat dijadikan partner untuk berbelanja dan menghabiskan uang bersama. Dalam suatu film tentu adanya pesan tersembunyi, untuk mengetahui isi pesan tersebut diperlukannya analisis wacana. Setelah melakukan analisis wacana dalam film "Crazy Rich Asian", penulis menemukan pesan bahwa uang memang menjadi salah satu kebutuhan dasar bagi setiap orang, tetapi tidak segala sesuatunya dapat diandalkan dengan uang.

\section{Ucapan Terima Kasih}

Penelitian yang telah dilakukan ini tidak akan terlaksana dengan baik tanpa adanya dukungan dan bantuan, serta kerja sama dari berbagai pihak yang telah membantu penulis hingga penelitian ini dapat diselesaikan tepat pada waktunya. Pada kesempatan ini, penulis ingin mengucapkan terima kasih kepada: Tuhan YME, orang tua, almamater, keluarga, dan teman-teman seperjuangan

\section{Daftar Pustaka}

Eriyanto. 2011. Analisis Wacana Pengantar Analisis Teks Media. Yogyakarta: LKis Printing Cemerlang.

Sukendro G. G., \& Ovilia Kurniawan (2017). Analisis Wacana nasionalisme Film Dalam Film 5CM. Koneksi, Vol.1, No.2 (p.531-536). https://journal.untar.ac.id/index.php/koneksi/article/view/2036

Imam Gunawan. 2014. Metode Penelitian Kualitatif Teori dan Praktik. Jakarta: Bumi Aksara.

Moh. Nazir. 2011. Metode Penelitian. Bogor: Ghalia Indonesia. 
Ngalimun. 2017. Ilmu Komunikasi Sebuah Pengantar Praktis. Yogyakarta: Pustaka Baru Press.

Marta, Rustono Farady. (2015). Analisis Wacana Kritis Film "Puteri Giok" Cermin Asimilasi Paksa Era Orde Baru. Jurnal Komunikasi, Vol.17, No.1 (p.331-346). http://jmb.lipi.go.id/index.php/jmb/article/viewFile/323/274

Vinna Sri Yuniarti. (2015). Perilaku Konsumen Teori dan Praktik. Bandung: Pustaka Setia.

Karunia, A. L., \& Widayatmoko. (2018). Gaya Hidup Remaja Perempuan dalam Membentuk Body Image dan Citra Diri Sesuai Tren Masa Kini. Koneksi, Vol.2, No.1 (p.30-36). https://journal.untar.ac.id/index.php/koneksi/article/view/2426 